\title{
Changes in Meat Quality and Natural Di-peptides in the Loin and Ham Cuts of Korean Native Black Pigs during Cold Storage
}

\author{
Dongwook Kim', Juae Gil', Hee-Jin Kim', Hyun-Wook Kim², Beom-Young Park², Sung-Ki Lee ${ }^{1}$ and \\ Aera Jang *
}

\author{
${ }^{1}$ Department of Animal Products and Food Science, Kangwon National University, Chuncheon 200-701, Korea \\ ${ }^{2}$ National Institute of Animal Science, RDA, Suwon 441-706, Korea
}

Received October 3, 2013 /Revised November 30, 2013 /Accepted December 2, 2013

\begin{abstract}
The aim of this study was to evaluate changes in the meat quality and natural di-peptide (carnosine and anserine) content in the loin and ham cuts of female, Korean Native Black Pigs (KNBP) during cold storage for 10 days. The $\mathrm{pH}$ value of the loin and the ham cuts increased with an increase in the number of storage days. The lightness $\left(\mathrm{L}^{*}\right)$ of the loin cuts did not show any significant difference; however, the lightness of the ham cuts was decreased at storage day $10(p<0.05)$. The redness $\left(\mathrm{a}^{*}\right)$ of the ham was higher than the redness of the loin $(p<0.05)$ during the entire 10-days of storage. The water holding capacity of the loin was decreased from $78.5 \%$ to $67.9 \%$ during storage $(p<0.05)$. The total number of microorganisms and coliforms was increased in both the loin and the ham during storage, and the initial total microbial contamination was higher in the ham cut $(5.16 \log \mathrm{CFU} / \mathrm{g})$ than it was in the loin cut (4.87 log CFU/g). The carnosine content of the loin and the ham was in the range of 1.12-1.35 $\mathrm{mg} / \mathrm{ml}$ and no significant difference was found between those two pork cuts. The anserine content of the ham cut was higher than it was in the loin cut until storage day 3 . The ratio of carnosine and anserine increased with an increase in the number of storage days and it ranged from 27.6-59.7 for the loin cut and from 20.1-51.2 for the ham cut. The 2,2-diphenyl-1-picrylhydrazyl (DPPH) radical scavenging activity of the loin and the ham cuts significantly decreased as the number of storage days increased. For both types of KNBP cuts, lipid oxidation and volatile basic nitrogen significantly increased after storage day 5. These results found that natural antioxidants carnosine and anserine decreased as the number of storage days increased, and anserine decreased more rapidly than carnosine $(p<0.05)$.
\end{abstract}

Key words : Anserine, antioxidation, carnosine, Korean native black pig, quality

\section{서 론}

Carnosine ( $\beta$-alanyl-L-histidine)과 anserine ( $\beta$-alanyl-L-1methylhistidine)은 imidazole di-peptide로 척추동물의 골격 근과 신경조직에 특히 많이 분포하고 있고[3] 금속 킬레이터와 유리라디칼 소거제로서의 역할을 한다고 알려져 있다[5]. 특히 anserine은 carnosine의 N-methylated 유도체로서 포유류 보 다는 가금육과 같은 비포유동물의 근육에 많이 함유되어있고 carnosine과 유사한 기능을 한다[2]. 이들 di-peptide는 유리라 디칼 종류로부터 신체의 독소제거, 막을 보호, proton 완충효 과, 면역조절에 관여하는 대식세포조절기능을 갖고 있다[11]. Carnosine은 그 구성 아미노산을 이용해 조직내 carnosine합 성효소와 분해효소에 의해 생성 및 분해되며[2] 조직 내에서

\section{*Corresponding author}

Tel : +82-33-250-8643, Fax : +82-33-251-7719

E-mail : ajang@kangwon.ac.kr

This is an Open-Access article distributed under the terms of the Creative Commons Attribution Non-Commercial License (http://creativecommons.org/licenses/by-nc/3.0) which permits unrestricted non-commercial use, distribution, and reproduction in any medium, provided the original work is properly cited.
유리된 상태로 존재하여 열수에 의해 쉽게 추출이 가능하다 [8]. Carnosine 함량은 동물의 종, 성별, 연령, 육종에 따른 동물 근육의 종류에 의해 영향을 받을 수 있다[25, 27].

최근 국내 소비자의 식품소비수준의 향상과 식생활의 서구 화로 인해 식육의 섭취가 1 인당 $40.5 \mathrm{~kg}$ 으로 점차 증가하고 있으나 비만, 고혈압, 뇌 질환과 같은 성인병의 원인이 식육이 라는 의견도 대두되면서 육류의 소비에 대한 부정적인 인식이 증가하고 있다 $[6,26]$. 한국인들은 지방이 많이 침착되어 고소 한 맛을 내는 삼겹살을 특히 선호하기 때문에 다른 등심, 앞다 리, 사태, 후지 등과 같은 저지방 부위와 비교하여 소비의 불균 형이 매우 심각하다. 2012년 국내 돼지고기 생산량은 749.2톤 이며 삼겹살과 목심과 같은 선호부위의 생산량은 220.8톤으로 $29.5 \%$ 에 불과하나 비선호되는 저지방부위는 약 $70.5 \%$ 의 생산 량을 차지하고 있으나 소비가 되지 않아 적체되고 있다[26]. 그러나 돼지고기는 적육의 경우 매우 훌륭한 단백질, 필수지 방산, 미네랄 등의 공급원으로서 반드시 섭취해야 하는 식품 이다[29]. 국내 돼지고기 공급의 대부분을 차지하는 개량종 비 육돈은 산자수가 많고 성장이 빠르고 육 생산량이 많도록 랜 드레이스(L), 요크셔 $(\mathrm{Y})$, 듀록종 $(\mathrm{D})$ 등을 교배하여 생산되는 $\mathrm{LYD}$ 혹은 YLD와 같은 3원 교잡종이 흔히 이용되고 있다[16, 
20]. 반면에 우리나라 재래돼지는 개량종에 비해 유전적 특징 으로 체격이 왜소하고 피모가 흑색이고 열악한 환경에서도 잘 견디나 만숙종인 특징이 있다[21]. 그러나 육질부분에서는 다른 품종에 비하여 지방이 단단하고 맛이 좋고 쫄깃하고 부 드러운 식감으로 우리나라 사람들의 기호에 적합한 것으로 알려져 있다[20]. 또한 육색이 붉고 지방이 백색이며 섬유소가 많고 가늘어 연하다 $[7,15]$. 한편, 재래흑돼지의 육색이 더 붉고 기호성이 높아 소비자들의 관심이 증대되면서 삼겹살과 목살 이 비싼 가격에 소비되고 있지만 지방함량이 낮고 고 단백질인 등심과 후지는 소비가 부진한 상태이다. 또한 재래흑돼지의 적육부위인 등심과 후지 내 존재하는 항산화 기능성을 갖는 di-peptide인 carnosine과 anserine에 대한 연구도 많지 않다. 따라서 본 연구는 암컷 재래 흑돼지의 저지방 부위육인 등심 과 후지의 냉장 저장 중의 품질과 항산화 기능성 di-peptide인 carnosine과 anserine의 함량변화를 규명하기 위해 실시하였다.

\section{재료 및 방법}

\section{재래흑돼지 시료처리}

재래흑돼지 시료는 강원도 홍천의 재래흑돼지 사육 농가에 서 7개월 사육한 체중 $60 \sim 70 \mathrm{~kg}$ 의 재래흑돼지(암컷)를 도축하 여 얻은 등심과 후지육을 구입하여 이용하였다. 결체조직과 지방을 제거하고 호기적 조건으로 비닐 포장하여 $4{ }^{\circ} \mathrm{C}$ 냉장실 에 10 일간 저장하며 품질과 di-peptide의 변화를 분석하였다.

\section{$\mathrm{pH}$}

$\mathrm{pH}$ 는 재래돈육 $10 \mathrm{~g}$ 을 $90 \mathrm{ml}$ 의 증류수와 함께 homogenizer (PolyTron ® PT-2500 E, Kinematica, Lucerne, Switzerland)로 균질화한 후 $\mathrm{pH}$ meter (Orion 230A, Thermo Fisher Scientific, Inc., Waltham, MA, USA)로 측정하였다.

\section{색도}

색도는 색차계(Colormeter CR-300, Minolta Co., Tokyo, Japan)를 이용하여 L* (Lightness, 명도), $\mathrm{a}^{*}$ (Redness, 적색도), $\mathrm{b}^{*}$ (Yellowness, 황색도) 값을 동일한 방법으로 반복 측정하여 평균값을 나타내었다. 이때 표준색은 Y값이 $93.60, x$ 값이 $0.3134, \mathrm{y}$ 값이 0.3194 인 표준백판을 사용하여 측정하였다.

\section{보수력}

보수력(water-holding capacity, WHC)은 Hofmann 등의 방법[12]에 따라 여과지 압착법에 의해 측정하였다. Plexiglass plate $(11.5 \times 5.0 \times 0.8 \mathrm{~cm})$ 위에 Whatman No.1 여과지를 올려 놓고, 여과지 중앙에 재래돈육 $0.3 \mathrm{~g}$ 을 올려놓은 다음 plexi-glass plate로 덮고 동일한 힘으로 나사를 조여 5 분 동안 방치하였다. 이후 digitizing area-line meter (Super PLANIXa, Tamaya Technics Inc., Tokyo, Japan)를 사용하여 내부의
시료면적과 총면적을 측정한 백분율(\%)로 계산하였다.

\section{미생물}

일반세균과 대장균군은 Petrifilm ${ }^{\mathrm{TM}}$ (Aerobic count plate, Coliform count plate, $3 \mathrm{M}, \mathrm{USA}$ )을 사용하여 제조사의 방법에 따라 수행하였다. 재래돈육 $10 \mathrm{~g}$ 을 채취한 다음 $0.1 \%$ 멸균 펩 톤수 $90 \mathrm{ml}$ 을 멸균 bag에 넣고, stomacher (Bag Mixer 400, St Nom, Interscience, France)를 이용하여 4분 동안 균질화 하였다. 균질액을 거즈를 이용하여 거르고, 추출한 추출물을 $0.1 \%$ 멸균 펩톤수로 희석하여 Petrifilm에 $1 \mathrm{ml}$ 를 접종하여 $37^{\circ} \mathrm{C}$ 에서 48 시간 배양한 후, 군락 수를 계수하였다.

\section{Di-peptide (carnosine과 anserine) 함량}

재래 돈육 내 di-peptide 함량은 Gil-Agusti 등의 방법[10]을 변형하여 분석하였다. 재래돈육 $3 \mathrm{~g}$ 에 $15 \mathrm{ml}$ 의 증류수를 첨가 하여 $15,000 \mathrm{rpm}$ 에서 40 초 동안 균질화 시키고, 균질액을 $3,000 \mathrm{rpm}$ 에서 10 분 동안 원심분리를 하였다. Whatman No.1 여과지를 이용하여 여과 후 클로로포름을 첨가하여 30 초 동안 흔들어 준 다음 원심분리 $\left(3,000 \mathrm{rpm}, 4^{\circ} \mathrm{C}, 10 \mathrm{~min}\right)$ 하고, 상등액 을 di-peptide 분석을 위한 HPLC 시료로 사용하였다. 강원대 학교 공동실험실습관에서 보유한 HPLC (Agilent Technologies 1260 Infinity, Santa Clara, CA, USA)를 이용하였으며, 분석 컬럼은 zorbax eclipse XDB-C18 $(250 \times 4.6 \mathrm{~mm}, 5 \mu \mathrm{m}$, Agilent, Palo Alto, CA, USA)을 사용하였다. 컬럼 온도는 2 $5^{\circ} \mathrm{C}$ 이었고 UV 흡광도 $210 \mathrm{~nm}$ 에서 측정하였다. 이동상 용매는 $0.01 \mathrm{M}$ sodium dodecyl sulfate를 $0.01 \mathrm{M}$ sodium dihydrogen phosphate ( $\mathrm{pH}$ 7.0)에 용해하여 사용하였으며, $0.1 \mathrm{M}$ sodium hydroxide로 $\mathrm{pH}$ 를 7.0 으로 보정하였다. 유속은 $1 \mathrm{ml} / \mathrm{min}$ 으 로 20 분 동안 분석하였으며, 시료는 $20 \mu 1$ 를 주입하여 분석하 였다. 모든 시약 및 시료는 $0.45 \mu \mathrm{m}$ membrane filter를 이용하 여 여과하여 사용하였다. 표준물질로 carnosine과 anserine은 Sigma (St. Louis, Missouri, USA)로부터 구입하여 처리농도에 따른 면적의 비율을 이용하여 일차방정식을 이용하여 함량을 분석하였다(Fig. 1).

\section{2,2-diphenyl-1-picrylhydrazyl (DPPH) 라디칼 소거활성}

$\mathrm{DPPH}$ 라디칼 소거능은 시료의 항산화 활성을 평가하기 위하여 Blois [1]의 방법을 응용하여 측정하였다. 메탄올에 용 해시킨 $0.2 \mathrm{mM} \mathrm{DPPH} 1 \mathrm{ml}$ 에 각 시료 $1 \mathrm{ml}$ 을 혼합하여 암실에 서 30분간 반응시킨 뒤, UV/VIS spectrophotometer (Molecular Device, M2e, USA)을 사용하여 $517 \mathrm{~nm}$ 에서 흡광도를 측 정하였다. DPPH 라디칼 소거능은 아래의 식에 따라 계산하였 으며, 양성대조군은 ascorbic acid $(20 \mathrm{\mu g} / \mathrm{ml})$ 를 사용하였다.

DPPH 라디칼 소거활성 $(\%)=1$-(시료의 흡광도-Reference 흡광도)/대조구 흡광도 $\times 100$ 


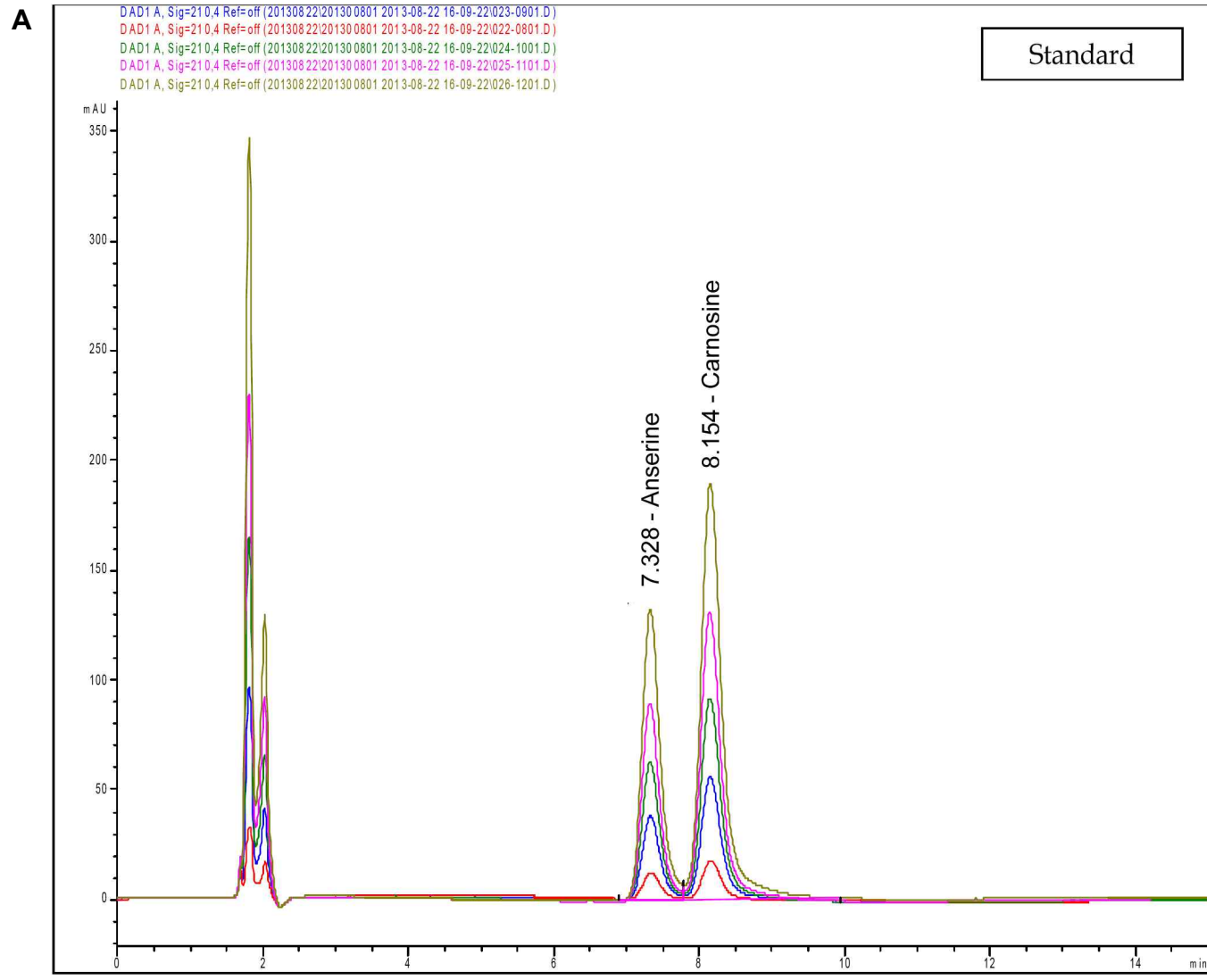

B
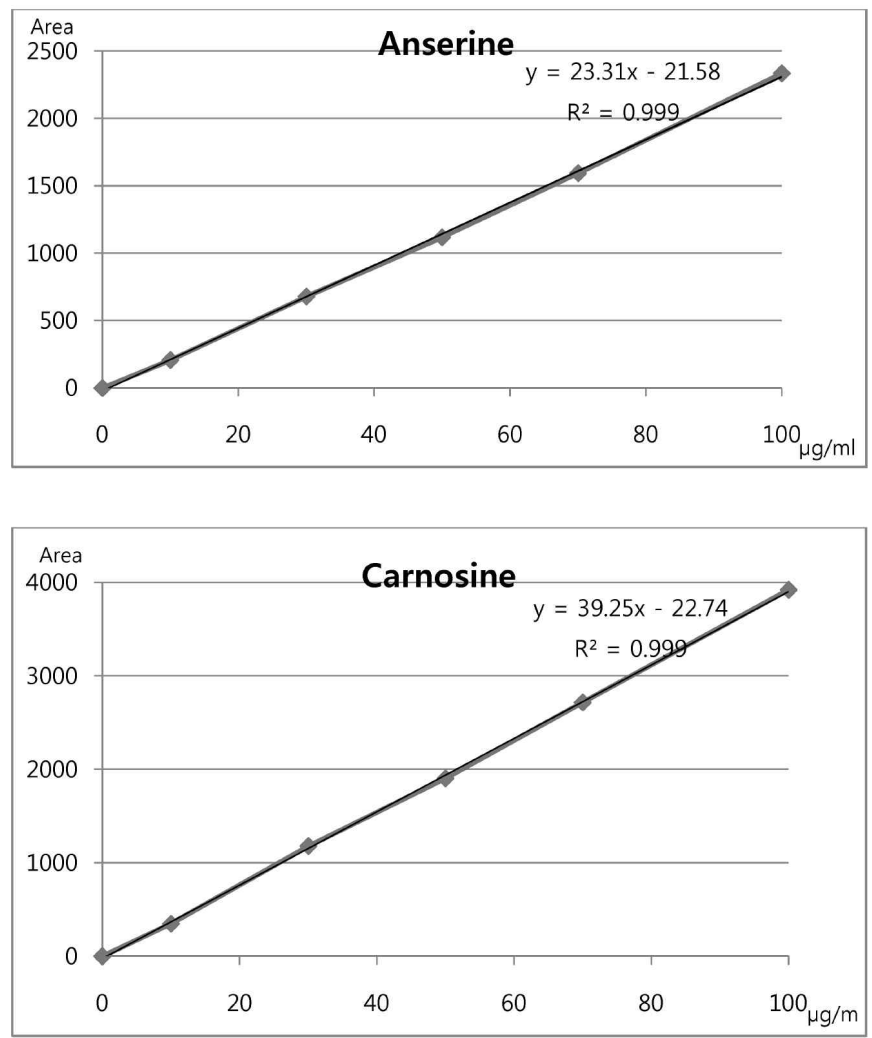

Fig. 1. High pressure liquid chromatogram (A), standard curve and linear equation of di-peptide (B, anserine and carnosine). 
* 대조구 흡광도 $=$ Distilled water (DW) $1 \mathrm{ml}+0.2 \mathrm{mM}$ DPPH solution (in methanol) $1 \mathrm{ml}$

* Reference $=\mathrm{DW} 1 \mathrm{ml}+$ methanol $1 \mathrm{ml}$

\section{2-Thiobarbituric acid reactive substances (TBARS)}

지방산패도를 의미하는 TBARS는 Witte 등[30]의 방법을 이 용하여 측정하였다. 재래돈육 $10 \mathrm{~g}$ 을 취하여 $20 \%$ 의 trichloroacetic acid (in 2M phosphoric acid)를 $25 \mathrm{ml}$ 첨가하고, 14,000 rpm에서 30초 동안 homogenizer (PolyTron ${ }^{\circledR}$ PT-2500 E, Kinematica, Lucerne, Switzerland)를 이용하여 균질화하였 다. 균질액이 $50 \mathrm{ml}$ 가 되도록 증류수를 첨가한 후, 원심분리 $\left(3,000 \mathrm{rpm}, 4^{\circ} \mathrm{C}, 10 \mathrm{~min}\right)$ 한 다음, Whatman No.1 여과지를 이용하여 여과하였다. 여과액 $5 \mathrm{ml}$ 에 $0.005 \mathrm{mM}$ 2-thiobarbituric acid $5 \mathrm{ml}$ 을 첨가 한 후 실온 암소에서 15시간 방치 하였고 UV/VIS spectrophotometer (molecular Device, M2e, USA) 를 이용하여 $530 \mathrm{~nm}$ 에서 흡광도를 측정하고 아래의 식에 의하여 계산하였다.

TBARS (mg of malondialdehyde (MDA)/ $\mathrm{kg}$ sample) = (시료흡광도-공시료흡광도)×5.2

휘발성 염기태 질소(Volatile basic nitrogen, VBN )

단백질 변패정도를 나타내는 VBN 함량은 Jang 등[14]의 conway unit을 사용한 미량확산법을 이용하여 측정하였다. 재래돈육 $10 \mathrm{~g}$ 에 증류수 $90 \mathrm{ml}$ 을 넣고, homogenizer (PolyTron ® PT-2500 E, Kinematica, Lucerne, Switzerland)로 $14,000 \mathrm{rpm}$ 에서 20초 동안 균질화 하였다. 균질액을 원심분리 $\left(3,000 \mathrm{rpm}, 4^{\circ} \mathrm{C}, 10 \mathrm{~min}\right)$ 한 다음 Whatman No.1 여과지를 이용하여 여과하였다. 여과액 $1 \mathrm{ml}$ 을 conway unit 외실에 넣 고, 내실에는 $0.01 \mathrm{~N}$ boric acid $1 \mathrm{ml}$ 와 conway reagent 50 $\mu \mathrm{l}$ (0.066\% methyl red/60\% EtOH : bromocresol green/20\% $\mathrm{EtOH}=1: 1)$ 을 첨가하였다. 뚜껑과 접착부위에 글리세린을 바 르고 닫은 후 $50 \%$ potassium carbonate $1 \mathrm{ml}$ 을 외실에 주입하 고 즉시 밀폐한 다음 용기를 수평으로 교반시킨 후 $37^{\circ} \mathrm{C}$ 에서 120 분간 방치하고 $0.02 \mathrm{~N}$ 황산으로 적정하여 무색이 되는 양 을 측정하고, 아래의 식을 이용하여 계산하였다. $\mathrm{a}$ 는 시료를 적정한 황산의 부피 $(\mathrm{ml}), \mathrm{b}$ 는 공시료를 적정한 황산의 부피 $(\mathrm{ml}), \mathrm{f}$ 는 $0.02 \mathrm{~N}$ 황산의 표준화 지수, $\mathrm{S}$ 는 시료 무게 $(\mathrm{g})$ 이다.

$\operatorname{VBN}(\mathrm{mg} \%)=(\mathrm{a}-\mathrm{b}) \times \mathrm{f} \times 28.014 \times 100 / \mathrm{S}$

\section{통계분석}

본 실험의 모든 결과는 SAS program (ver. 9.2 Statistics Analytical System)의 General Linear Model 방법을 이용하여 분산 분석하였다. 처리군의 평균값 간의 비교를 위해 Duncan's multiple range test를 이용하여 5\% 수준에서 유의성 검 정을 실시하였다.

\section{결과 및 고찰}

$\mathrm{pH}$

신선돈육의 품질에 영향하는 주요 요인은 사후 $\mathrm{pH}$, 육색, 보수력, 풍미 연도 등이며 재래흑돼지 등심과 후지육의 냉장 저장기간 동안의 $\mathrm{pH}$ 변화는 Table 1에 나타내었다. 등심과 후지육은 저장 기간이 증가하면서 $\mathrm{pH}$ 값이 증가함을 나타내었 으며 저장 10 일차에 가장 높은 $\mathrm{pH}$ 수준을 나타내었다( $p<0.05)$. 저장 1 일에서 7일까지는 $\mathrm{pH}$ 값이 5.43 5.61 범위를 보였으나 저장 10 일에는 6.15 6.17으로 증가함을 나타내었다. 돈육의 $\mathrm{pH}$ 는 성별, 축종, 연령, 근육 부위 등에 의해 차이가 있으며 $[22,24]$ 생축의 근육의 $\mathrm{pH}$ 는 약 7.2 이지만 도축 후 글리코겐의 분해로 생산된 젖산이 축적되어 근육 $\mathrm{pH}$ 가 감소하여 도축 24 시간 후는 $\mathrm{pH}$ 가 5.4 5.8에 이른다[23]. 그러나 재래흑돼지 등 심과 후지육은 저장 기간이 증가함에 따라 $\mathrm{pH}$ 도 증가하였는 데 이는 단백질의 완충물질의 변화, 전해질 해리감소, 암모니 아의 생성에 의한 것으로 판단된다[9]. 부위별 차이에 의한 $\mathrm{pH}$ 변화를 살펴본 결과 저장 1 일에서 7 일까지는 등심부위보다는 후지육 부위의 $\mathrm{pH}$ 가 유의적으로 높은 수준을 보였으나 저장 10 일에는 등심과 후지육 사이의 유의적인 차이는 볼 수 없었 다. Choi 등[7]은 약 210 270일령의 재래 흑돼지의 사후 24시 간 후의 $\mathrm{pH}$ 가 6.02로 보고하여 본 연구결과보다 높은 수준을 보인 것으로 판단된다. $\mathrm{Kim}$ 등[20]은 제주 재래돼지의 암컷과 수컷의 등심의 $\mathrm{pH}$ 가 각각 5.58과 5.62이라고 하였고 Kang과 Lee [19]는 재래종 돼지 등심의 진공포장 저장 중의 $\mathrm{pH}$ 변화를 측정한 결과 5.5 5.6 사이의 값을 보이며 개량종 돼지보다 유 의적으로 낮은 $\mathrm{pH}$ 범위를 보인다고 하여 본 연구결과와 유사 한 결과를 보고하였다.

\section{육색}

재래흑돼지 등심과 후지육의 냉장 저장기간 동안의 육색의

Table 1. $\mathrm{pH}$ changes of loin and ham of Korean native black pig during cold storage

\begin{tabular}{ccccc}
\hline & \multicolumn{4}{c}{ Storage days } \\
\cline { 2 - 5 } Treatment $^{1)}$ & 1 & 3 & 5 & 7 \\
\hline Loin & $5.43 \pm 0.003^{\mathrm{Db}}$ & $5.44 \pm 0.015^{\mathrm{Db}}$ & $5.48 \pm 0.003^{\mathrm{Cb}}$ & $5.59 \pm 0.006^{\mathrm{Bb}}$ \\
Ham & $5.48 \pm 0.005^{\mathrm{Da}}$ & $5.51 \pm 0.006^{\mathrm{Ca}}$ & $5.50 \pm 0.009^{\mathrm{Ca}}$ & $5.61 \pm 0.005^{\mathrm{Ba}}$ \\
\hline
\end{tabular}

\footnotetext{
${ }^{\mathrm{A}-\mathrm{D}}$ Means \pm SE within same row with different superscript letters differ significantly at $p \ll 0.05$.
}

${ }^{a-b}$ Means \pm SE within same column with different superscript letters differ significantly at $p<0.05$. 
Table 2. Color of loin and ham of Korean native black pig during cold storage

\begin{tabular}{ccccccc}
\hline & & \multicolumn{5}{c}{ Storage days } \\
\cline { 3 - 7 } & Treatment ${ }^{1)}$ & 1 & 3 & 5 & 7 & 10 \\
\cline { 3 - 7 } $\mathrm{L}^{*}$ & Loin & $57.26 \pm 0.397^{\mathrm{Aa}}$ & $57.77 \pm 0.778^{\mathrm{Aa}}$ & $57.71 \pm 0.220^{\mathrm{Aa}}$ & $57.66 \pm 0.367^{\mathrm{Aa}}$ & $56.45 \pm 0.360^{\mathrm{Aa}}$ \\
& Ham & $55.62 \pm 0.241^{\mathrm{Ab}}$ & $55.11 \pm 0.326^{\mathrm{Ab}}$ & $55.41 \pm 0.168^{\mathrm{Ab}}$ & $54.86 \pm 0.106^{\mathrm{Ab}}$ & $53.18 \pm 0.416^{\mathrm{Bb}}$ \\
\hline \multirow{2}{*}{$\mathrm{a}^{*}$} & Loin & $7.64 \pm 0.444^{\mathrm{Ab}}$ & $7.54 \pm 0.773^{\mathrm{Ab}}$ & $7.23 \pm 0.050^{\mathrm{Ab}}$ & $6.34 \pm 0.064^{\mathrm{ABb}}$ & $5.47 \pm 0.152^{\mathrm{Bb}}$ \\
& Ham & $10.33 \pm 0.190^{\mathrm{Aa}}$ & $10.58 \pm 0.186^{\mathrm{Aa}}$ & $9.58 \pm 0.092^{\mathrm{ABa}}$ & $9.16 \pm 0.406^{\mathrm{Ba}}$ & $8.61 \pm 0.582^{\mathrm{Ba}}$ \\
\hline \multirow{2}{*}{$\mathrm{b}^{*}$} & Loin & $2.88 \pm 0.092^{\mathrm{Bb}}$ & $3.72 \pm 0.460^{\mathrm{Bb}}$ & $6.48 \pm 0.488^{\mathrm{Aa}}$ & $6.87 \pm 0.468^{\mathrm{Aa}}$ & $6.76 \pm 0.512^{\mathrm{Aa}}$ \\
& Ham & $5.31 \pm 0.091^{\mathrm{Ba}}$ & $5.97 \pm 0.747^{\mathrm{Ba}}$ & $6.14 \pm 0.137^{\mathrm{Ba}}$ & $6.11 \pm 0.199^{\mathrm{Ba}}$ & $7.83 \pm 0.458^{\mathrm{Aa}}$ \\
\hline
\end{tabular}

${ }^{\mathrm{A}-\mathrm{B}}$ Means \pm SE within same row with different superscript letters differ significantly at $p<0.05$.

${ }^{\mathrm{a}-\mathrm{b}}$ Means \pm SE within same column with different superscript letters differ significantly at $p<0.05$.

변화는 Table 2에 나타내었다. 명도를 나타내는 $\mathrm{L}^{*}$ 값은 등심의 경우 저장기간 동안 유의적인 변화를 보이지 않았으나 후지육 의 경우는 저장 10 일째 감소함을 나타내었다. 등심과 후지육 의 $\mathrm{L}^{*}$ 값을 비교한 결과 모든 저장기간 동안 등심이 후지육보 다 높은 $\mathrm{L}^{*}$ 값을 나타내었다. 적색도를 나타내는 $\mathrm{a}^{*}$ 값은 저장 7 일까지는 유의적인 변화가 없었으나 저장 10 일에 유의적인 감소를 보였으며 후지육의 경우에는 저장 7일부터 적색도가 감소함을 나타내었다. 등심과 후지육 사이의 적색도는 후지육 의 $a^{*}$ 값이 모두 높은 수준을 나타내었다. 갈색도를 나타내는 $\mathrm{b}^{*}$ 값은 등심의 경우 저장 1 일과 3 일까지는 낮은 수준을 보였으 나 저장 5 일부터 유의적으로 증가하여 저장 10 일까지 높은 수준으로 유지됨을 나타내었다. 후지육의 경우는 $b^{*}$ 값이 저장 7 일까지 차이를 보이지 않다가 저장 10 일에 유의적으로 증가 함을 나타내었다. Jin 등[15]은 재래종 돈육 등심의 $\mathrm{L}^{*} \mathrm{a}^{*}, \mathrm{~b}^{*}$ 값 이 모두 랜드레이스 돈육 등심의 값보다 높았다고 하였고 Kang과 Lee [19]는 재래흑돼지육이 개량종 돼지고기보다 $\mathrm{a}^{*}$ 값 이 높다고 하였다. 육색은 식육의 품질을 대표하는 것으로 특 히 $\mathrm{a}$ *값은 신선육의 관능적인 기호성에 밀접한 관계를 갖고 있는 요인으로서 소비자들에게 긍정적으로 인식되는 부분으 로 판단된다. 등심의 경우 저장 7 일까지는 $\mathrm{a}^{*}$ 값이 차이를 보이 지 않아 유통이 안전할 것으로 판단된다. 등심보다 후지육의 $a^{*}$ 값과 $b^{*}$ 값이 높은 이유는 210 일령 도축되는 재래돼지고기가 붉은 육색과 마블링이 잘 침착되는 특징을 가지므로[6] 마블링 이 축적될 수 있는 등심육이 후지육보다는 밝고 적색도와 갈 색도가 낮게 표출되는 것으로 판단된다.

\section{보수력}

재래흑돼지 등심과 후지육의 냉장 저장기간 동안의 보수력 의 변화는 Table 3 에 나타내었다. 등심의 경우 냉장 저장 7 일부 터 보수력이 유의적으로 감소함을 보였으며 후지육의 경우 저장기간에 따른 보수력의 변화가 일정한 경향을 보이지 않았 다. 또한 등심과 후지육의 부위에 따른 보수력은 저장 1 일차에 는 차이가 없고 저장 3 7일 동안은 후지육에서만 높은 수준을 보여 이에 대한 추가적인 연구가 필요할 것으로 판단된다.

\section{미생물 특성}

재래흑돼지 등심과 후지육의 냉장 저장기간 동안의 총균수 와 대장균군수의 변화는 Table 4 에 나타내었다. 흑돼지 육의 저장 초기 총균수는 등심과 후지육이 각각 4.87 과 $5.16 \mathrm{log}$ $\mathrm{CFU} / \mathrm{g}$ 을 보였으며 저장 기간이 증가함에 따라 유의적으로 증가함을 나타내어 저장 10 일의 경우는 모두 $8.0 \log \mathrm{CFU} / \mathrm{g}$ 을 넘어 부패의 수준으로 진행된 것으로 판단되었다. 재래 흑돼 지 등심보다는 후지육의 총균수가 유의적으로 높았으나 저장 10 일에 이르러서는 부위에 따른 미생물 수에 유의적인 차이를 보이지 않았다. 또한 대장균군수도 저장기간이 증가하면서 유 의적으로 증가하였으며 저장 5일과 7일은 등심이 후지육보다 낮은 대장균군 수를 나타내었다( $p<0.05)$. 이는 도축 후 지육을 부분육으로 분리 시, 등심보다는 후지육이 미생물 오염이 높 았음을 보인 것으로 판단된다.

\section{Di-peptide (carnosine과 anserine) 함량}

재래흑돼지 등심과 후지육의 냉장 저장기간 동안의 carnosine과 anserine 함량 및 비율은 Table 5에 나타내었다. 등심과

Table 3. Water holding capacity (WHC) of loin and ham of Korean native black pig during cold storage

\begin{tabular}{cccccc}
\hline Treatment $^{1)}$ & \multicolumn{5}{c}{ Storage days } \\
\cline { 2 - 6 } & 1 & 3 & 5 & 7 & 10 \\
\hline Loin & $78.50 \pm 1.066^{\mathrm{Aa}}$ & $77.23 \pm 1.265^{\mathrm{Ab}}$ & $76.16 \pm 0.337^{\mathrm{ABb}}$ & $73.90 \pm 1.240^{\mathrm{Bb}}$ & $67.94 \pm 0.775^{\mathrm{Ca}}$ \\
Ham & $78.92 \pm 0.445^{\mathrm{Ba}}$ & $82.60 \pm 0.630^{\mathrm{Aa}}$ & $83.02 \pm 0.842^{\mathrm{Aa}}$ & $78.55 \pm 0.983^{\mathrm{Ba}}$ & $72.64 \pm 2.025^{\mathrm{Ca}}$ \\
\hline
\end{tabular}

\footnotetext{
${ }^{\mathrm{A}-\mathrm{C}}$ Means \pm SE within same row with different superscript letters differ significantly at $p<0.05$.

${ }^{a-b}$ Means \pm SE within same column with different superscript letters differ significantly at $p<0.05$
} 
Table 4. Total microorganism and coliforms of loin and ham of Korean native black pig during cold storage (log CFU/g)

\begin{tabular}{ccccccc}
\hline & & & \multicolumn{5}{c}{ Storage days } \\
\cline { 3 - 6 } & Treatment & \multicolumn{5}{c}{10} \\
\hline Total & & 1 & 3 & 5 & 7 & 10 \\
Loin & $4.87 \pm 0.048^{\mathrm{Eb}}$ & $5.04 \pm 0.016^{\mathrm{Db}}$ & $5.50 \pm 0.046^{\mathrm{Cb}}$ & $6.56 \pm 0.061^{\mathrm{Bb}}$ & $8.41 \pm 0.025^{\mathrm{Aa}}$ \\
microorganisms & Ham & $5.16 \pm 0.058^{\mathrm{Ea}}$ & $5.35 \pm 0.028^{\mathrm{Da}}$ & $6.15 \pm 0.061^{\mathrm{Ca}}$ & $6.98 \pm 0.052^{\mathrm{Ba}}$ & $8.47 \pm 0.042^{\mathrm{Aa}}$ \\
\hline \multirow{2}{*}{ Colifroms } & Loin & $2.67 \pm 0.066^{\mathrm{Da}}$ & $2.78 \pm 0.095^{\mathrm{Da}}$ & $3.04 \pm 0.081^{\mathrm{Cb}}$ & $3.35 \pm 0.071^{\mathrm{Bb}}$ & $4.36 \pm 0.090^{\mathrm{Aa}}$ \\
& Ham & $2.84 \pm 0.026^{\mathrm{Da}}$ & $3.05 \pm 0.029^{\mathrm{Da}}$ & $3.73 \pm 0.031^{\mathrm{Ca}}$ & $4.34 \pm 0.084^{\mathrm{Ba}}$ & $4.87 \pm 0.290^{\mathrm{Aa}}$ \\
\hline
\end{tabular}

${ }^{\mathrm{A}-\mathrm{E}}$ Means \pm SE within same row with different superscript letters differ significantly at $p<0.05$.

${ }^{a-b}$ Means \pm SE within same column with different superscript letters differ significantly at $p \ll 0.05$

Table 5. Carnosine $(\mathrm{mg} / \mathrm{ml})$ and anserine $(\mu \mathrm{g} / \mathrm{ml})$ contents of loin and ham of Korean native black pig during cold storage

\begin{tabular}{ccccccc}
\hline & Treatment & \multicolumn{5}{c}{ Storage days } \\
\cline { 3 - 7 } & & 1 & 3 & 5 & 7 & 10 \\
\hline \multirow{2}{*}{ Carnosine } & Loin & $1.35 \pm 0.022^{\mathrm{Aa}}$ & $1.28 \pm 0.054^{\mathrm{ABa}}$ & $1.14 \pm 0.077^{\mathrm{Ba}}$ & $1.12 \pm 0.026^{\mathrm{Ba}}$ & $1.15 \pm 0.012^{\mathrm{Ba}}$ \\
& Ham & $1.27 \pm 0.010^{\mathrm{Aa}}$ & $1.30 \pm 0.002^{\mathrm{Aa}}$ & $1.18 \pm 0.028^{\mathrm{Ba}}$ & $1.17 \pm 0.010^{\mathrm{Ba}}$ & $1.17 \pm 0.039^{\mathrm{Ba}}$ \\
\hline \multirow{2}{*}{ Anserine } & Loin & $46.90 \pm 0.560^{\mathrm{Ab}}$ & $46.42 \pm 1.640^{\mathrm{Ab}}$ & $22.77 \pm 3.715^{\mathrm{Ba}}$ & $18.76 \pm 0.185^{\mathrm{Ba}}$ & $20.88 \pm 0.210^{\mathrm{Ba}}$ \\
& Ham & $61.46 \pm 0.730^{\mathrm{Aa}}$ & $64.68 \pm 1.115^{\mathrm{Aa}}$ & $57.91 \pm 11.525^{\mathrm{Aa}}$ & $23.08 \pm 1.785^{\mathrm{Ba}}$ & $22.85 \pm 1.420^{\mathrm{Ba}}$ \\
\hline \multirow{2}{*}{ Ratio $^{1)}$} & Loin & 28.78 & 27.57 & 50.07 & 59.70 & 55.08 \\
& Ham & 20.66 & 20.10 & 20.38 & 50.69 & 51.20 \\
\hline
\end{tabular}

${ }^{\mathrm{A}-\mathrm{B}}$ Means \pm SE within rows with different superscript letters are significantly different $(p<0.05)$.

${ }^{\mathrm{a}-\mathrm{b}}$ Means $\pm \mathrm{SE}$ within columns with different superscript letters are significantly different $(p<0.05)$.

${ }^{1)}$ Ratio of carnosine and anserine.

후지육에 함유된 carnosine 함량은 각각 $1.12 ~ 1.35 \mathrm{mg} / \mathrm{ml}$, $1.17 \sim 1.30 \mathrm{mg} / \mathrm{ml}$ 이었고 모두 저장 5 일 이후 carnosine 함량이 유의적으로 감소함을 나타내었으며 저장 5일 10일 동안은 carnosine 함량의 변화가 없었다. Anserine은 등심의 경우 저 장기간이 증가하면서 감소하였는데 특히 저장 5 일부터 유의 적으로 크게 감소하였으며 저장 7일째 후지육의 경우 저장 3 일에 보였던 anserine 함량에 비해 $64.3 \%$ 의 큰 감소를 나타내 었다( $p<0.05)$. 따라서 재래흑돼지 등심과 후지육의 carnosine 함량은 저장 3 일까지 유지되었고, anserine 함량의 경우는 등 심은 저장 3 일, 후지육의 경우는 저장 5 일까지 초기 농도가 유지됨을 나타내었다. Park 등[28]은 생 쇠고기와 익힌 쇠고기 의 carnosine농도가 각각 건조한 고기중량 당 274 와 277 $\mathrm{mg} / 100 \mathrm{~g}$ 으로 보고하였고 조리과정에 의한 carnosine 함량의 유의적인 변화는 없었으나 함량이 낮은 수준으로 나타난 것은 쇠고기에 지방함량이 높았기 때문이라고 하였다. 이는 carnosine이 골격근의 시토졸내에서 주로 존재하기 때문에 지방함
량이 높으면 근육 조직내 carsnosine 함량이 감소하기 때문이 다. 본 연구에서 제시한 등심과 후지육은 돼지 부분육에서도 지방함량이 낮은 부위로서 carnosine과 ansserine의 함량이 높 은 수준인 것으로 판단된다. 또한 carnosine과 anserine의 비율 을 살펴본 결과 저장 기간이 증가하면서 등심과 후지육 모두 증가하였으며 carnosine의 경우 특히 저장 5일째, anserine은 저장 7일 이후 급격한 증가를 나타내었다. 이는 저장 기간이 증가함에 따라 carnosine보다는 anserine의 감소 속도가 더욱 컸기 때문으로 판단된다. Gil-Agustí 등[10]은 시중 판매되는 분쇄 돈육 내 carnosine과 anserine의 함량을 측정한 결과 각 각 $2439 \pm 13$ 과 $50 \pm 2 \mu \mathrm{g} / \mathrm{g}$ 이었다고 하였고 48.78 의 비율을 보 여 본 연구결과와 유사한 수준을 나타내었다.

\section{$\mathrm{DPPH}$ 라디칼 소거능}

재래흑돼지 등심과 후지육의 냉장 저장기간 동안의 DPPH 라디칼 소거능은 Table 6에 나타내었다. 양성 대조군으로서

Table 6. DPPH radical scavenging activity of loin and ham of Korean native black pig during cold storage (\%)

\begin{tabular}{lcccccc}
\hline \multirow{2}{*}{$\begin{array}{c}\text { Treat } \\
\text { ment }\end{array}$} & Ascorbic acid & \multicolumn{5}{c}{ Storage days } \\
\cline { 3 - 6 } & $(20 \mu \mathrm{g} / \mathrm{ml})$ & 1 & 3 & 5 & 7 & 10 \\
\hline Loin & $79.37 \pm$ & $57.82 \pm 0.429^{\mathrm{Ba}}$ & $53.19 \pm 0.808^{\mathrm{Ca}}$ & $41.19 \pm 0.942^{\mathrm{Db}}$ & $36.28 \pm 0.722^{\mathrm{Ea}}$ & $22.84 \pm 0.657^{\mathrm{Fa}}$ \\
Ham & $0.573^{\mathrm{A}}$ & $58.44 \pm 0.850^{\mathrm{Ba}}$ & $54.51 \pm 1.346^{\mathrm{Ca}}$ & $46.09 \pm 0.074^{\mathrm{Da}}$ & $37.55 \pm 1.162^{\mathrm{Ea}}$ & $24.08 \pm 0.577^{\mathrm{Fa}}$ \\
\hline
\end{tabular}

${ }_{\mathrm{A}-\mathrm{F}}$ Means \pm SE within same row with different superscript letters differ significantly at $p<0.05$.

${ }^{a-b}$ Means \pm SE within same column with different superscript letters differ significantly at $p<0.05$ 
Table 7. 2-thiobarbituric acid reaction substance (TBARS) values of loin and ham of Korean native black pig during cold storage (mg MDA/kg meat)

\begin{tabular}{cccccc}
\hline \multirow{2}{*}{ Treatment $^{1)}$} & \multicolumn{5}{c}{ Storage days } \\
\cline { 2 - 6 } & 1 & 3 & 5 & 7 & 10 \\
\hline Loin & $0.065 \pm 0.001^{\mathrm{Ea}}$ & $0.084 \pm 0.002^{\mathrm{Db}}$ & $0.099 \pm 0.003^{\mathrm{Cb}}$ & $0.154 \pm 0.001^{\mathrm{Bb}}$ & $0.286 \pm 0.001^{\mathrm{Ab}}$ \\
Ham & $0.067 \pm 0.003^{\mathrm{Da}}$ & $0.099 \pm 0.005^{\mathrm{Ca}}$ & $0.110 \pm 0.001^{\mathrm{Ca}}$ & $0.174 \pm 0.004^{\mathrm{Ba}}$ & $0.354 \pm 0.009^{\mathrm{Aa}}$ \\
\hline
\end{tabular}

${ }_{\mathrm{A}-\mathrm{E}}$ Means \pm SE within same row with different superscript letters differ significantly at $p<0.05$.

${ }^{a-b}$ Means $\pm S E$ within same column with different superscript letters differ significantly at $p<0.05$

Table 8. Volatile basic nitrogen (VBN) of loin and ham of Korean native black pig during cold storage $(\mathrm{mg} \%)$

\begin{tabular}{cccccc}
\hline \multirow{2}{*}{ Treatment $^{1)}$} & \multicolumn{5}{c}{ Storage days } \\
\cline { 2 - 6 } & 1 & 3 & 5 & 7 & 10 \\
\hline Loin & $14.95 \pm 0.223^{\mathrm{Eb}}$ & $15.64 \pm 0.225^{\mathrm{Db}}$ & $16.74 \pm 0.261^{\mathrm{Cb}}$ & $20.44 \pm 0.193^{\mathrm{Bb}}$ & $39.93 \pm 0.223^{\mathrm{Ab}}$ \\
Ham & $16.57 \pm 0.477^{\mathrm{Da}}$ & $17.29 \pm 0.610^{\mathrm{Da}}$ & $18.52 \pm 0.112^{\mathrm{Ca}}$ & $21.54 \pm 0.110^{\mathrm{Ba}}$ & $43.22 \pm 0.225^{\mathrm{Aa}}$ \\
\hline
\end{tabular}

$\overline{\mathrm{A}-\mathrm{E}}$ Means \pm SE within same row with different superscript letters differ significantly at $p<0.05$.

${ }^{a-b}$ Means \pm SE within same column with different superscript letters differ significantly at $p<0.05$

ascorbic acid $(20 \mu \mathrm{g} / \mathrm{ml})$ 와 비교하였을 때 등심은 저장 1일차 에는 $\mathrm{DPPH}$ 라디칼 소거능이 $57.82 \%$ 이었으나 저장 기간이 증가함에 따라 유의적으로 감소함을 나타내었다. 또한 후지육 의 경우도 저장 1 일차에는 $58.44 \%$ 를 보였으나 저장 10 일차에 는 $24.08 \%$ 으로 소거능이 크게 감소함을 보였다( $p<0.05)$. Jo 등 [17]은 육계에 약용식물 추출물을 0.3 과 $1.0 \%$ 급여한 후 닭다 리육 추출물의 항산화 효과를 측정한 결과 $1.0 \%$ 급여구에서 유의적으로 높은 $\mathrm{DPPH}$ 소거능을 보였다고 하였고 Jang 등 [13]은 천연물 추출물을 급여한 후 닭 가슴육 추출물의 $\mathrm{DPPH}$ 라디칼 소거능이 증가하였다고 하여 식육 조직내 존재하는 항산화 물질에 의해 $\mathrm{DPPH}$ 라디칼 소거능이 증가할 수 있음을 제시하였다. 본 연구에서도 재래흑돼지 등심과 후지육의 DPPH 라디칼 소거능이 감소함을 알 수 있었는데 이는 Table 8에 제 시한 바와 같이 식육 조직 내 존재하는 di-peptide의 함량이 저장기간에 따라 감소함을 보였던 것과 일치하여 di-peptide 함량 감소에 따라 항산화 활성도 감소한 것으로 판단된다.

\section{2-Thiobarbituric acid reaction substance (TBARS)}

재래흑돼지 등심과 후지육의 냉장 저장기간 동안의 지방산 패도 변화는 Table 7에 나타내었다. 등심의 경우 저장기간이 증가함에 따라 유의적으로 TBARS값이 증가함을 나타내었으 며 이러한 경향은 후지육에서도 유사하게 나타났다 $(p<0.05)$. 등심과 후지육의 지방산패도를 비교하면 등심보다 후지육이 모든 저장기간 동안 유의적으로 높은 수준을 보였음을 나타내 었다. 저장 기간이 증가함에 따라 TBARS값이 증가한 것은 지 방 산화로 생성된 과산화물이 이차 산화생성물로 분해되었기 때문이고 미생물에 의한 대사와 지방분해 효소에 의해 생성된 분해물질에 의한 것으로 판단된다[4]. 특히 저장 3 일 이후부터 는 후지육에서의 TBARS값이 등심육보다도 유의적으로 높운 수준을 보인 것은 Table 6에 제시된 결과와 마찬가지로 후지육
에서 총균수가 높은 수준으로 오염되어 있어 미생물에 의한 대사 때문으로 판단된다. 지방의 산패 시점은 $0.20 \mathrm{mg} \mathrm{MDA} /$ $\mathrm{kg}$ 으로 규정하고 신선한 식육의 TBARS 범위를 이 수준 이하 로 간주되고 있어 $[4,14]$ 저장 10 일에는 지방산패가 진행된 것 으로 판단된다.

\section{단백질변패도(Volatile basic nitrogen, VBN)}

재래흑돼지 등심과 후지육의 냉장 저장기간 동안의 단백질 변패도 변화는 Table 8에 나타내었다. 저장기간이 증가하면서 $\mathrm{VBN}$ 값은 유의적으로 증가하였으며 저장 7 일 이후 $20 \mathrm{mg} \%$ 를 초과하였다. 우리나라는 원료육 및 포장육에 대해 휘발성염기 질소의 함량을 $20 \mathrm{mg} \%$ 으로 규정하고 있어[22] 저장 5일까지 는 재래 흑돼지의 등심과 후지육이 $20 \mathrm{mg} \%$ 이하의 값을 보여 선도를 유지한 것으로 판단되었으며 등심보다는 후지육의 $\mathrm{VBN}$ 값이 유의적으로 높은 수준을 나타내었다. VBN값은 식 품 단백질이 albumose, peptone, peptide, amino acid 등으로 분해된 후 미생물의 환원작용으로 생성되는 것으로 저장 중 VBN함량 증가는 미생물의 증식과 밀접한 관련이 있다[18]. 본 연구에서도 Table 6에 제시한 바와 같이 총균수가 저장 7일 에서 10 일 사이에 급격하게 증가하였고 $\mathrm{VBN}$ 값도 유의적으로 증가함을 보여 미생물 수에 의한 $\mathrm{VBN}$ 의 변화를 증명하였다. 즉, 총균수가 증가하면서 생기는 초기부패의 순간까지는 휘발 성염기태 질소의 증가가 작았지만 부패가 급격히 진행되면서 염기태 질소의 증가폭이 크게 증가하였기 때문에[22] 저장 7일 에서 10 일 사이의 증가량이 저장 1 일 5 일까지의 증가량보다 크게 나타난 것으로 판단된다.

\section{감사의 글}

본 연구는 농촌진흥청 신진연구자 지원연구과제(과제번호: 
PJ009809)와 2013년도 강원대학교 전임교원기본연구비 지원 에 의해 이루어진 것으로 이에 감사합니다.

\section{References}

1. Blois, M. S. 1958. Antioxidant determination by the use of a stable free radical. Nature 181, 1199-1200.

2. Boldyrev, A. A. and Severin, S. E. 1990. The histidine-containing dipeptides, carnosine and anserine: distribution, properties and biological significance. Adv Enzyme Regul 30, 175-194.

3. Bonfanti, L., Peretto, P., De Marchis, S. and Fasolo, A. 1999. Carnosine-related dipeptides in the mammalian brain. Prog Neurobiol 59, 333-353.

4. Brewer, M. S., Ikins, W. G. and Harbers, C. A. Z. 1992. TBA values, sensory characteristics and volatiles in ground pork during long-term frozen storage: Effects of packaging. J Food Sci 57, 558-563.

5. Chan, K. M. and Decker, E. A. 1994. Endogenous skeletal muscle antioxidants. Crit Rev Food Sci Nut 34, 403-426.

6. Cho, S. H., Park, B. Y., Kim, J. H., Kim, M. J., Seong, P. N., Kim, Y. J., Kim, D. H. and Ahn, C. N. 2007. Carcass yields and meat quality by live weight of Korean native black pigs. J Anim Sci Technol 49, 523-530.

7. Choi, Y. S., Park, B. Y., Lee, J. M., Lee, S. K. 2005. Comparison of carcass and meat quality characteristics between Korean native black pigs and commercial crossbred pigs. Korean J Food Sci Ani Resour 25, 322-327.

8. Christman, A. A. 1976. Factors affecting anserine and carnosine levels in skeletal muscles of various animals. Inter $J$ Biochem 7, 9-10.

9. Deymer, D. I. and Vanderkhove, P. 1979. Compounds determining $\mathrm{pH}$ in dry sausage. Meat Sci 3, 161-165.

10. Gil-Agustí, M., Esteve-Romero, J. and Carda-Broch, S. 2008. Anserine and carnosine determination in meat samples by pure micellar liquid chromatography. J Chromatogr A 1189, 444-450.

11. Guiotto, A., Calderan, A., Ruzza, P. and Borin, G. 2005. Carnosine and carnosine-related antioxidants: a review. Curr Med Chem 12, 2293-2315.

12. Hofmann, K., Hamm, R. and Bluchel, E. 1982. NeunesUber die bestimmung der wasserbindung des fleisches mit hilfe der filterpapierpress methode. Fleischwiry 62, 87-92.

13. Jang, A., Liu, X. D., Shin, M. H., Lee, B. D., Lee, S. K., Lee, J. H. and Jo, C. 2008. Antioxidative potential of raw breast meat from broiler chicks fed a dietary medicinal herb extract mix. Poult Sci 87, 2382-2389.

14. Jang, A., Park, J. E., Kim, S. H., Chae, H. S., Ham, J. S., Oh, M. H., Kim, H. W., Seol, K. H., Cho, S. H. and Kim, D. H. 2010. Effect of dietary supplementation of quercetin on oxidative stability of chicken thigh. Korean J Poult SCi 37, 405-413.

15. Jin, S. K., Kim, C. W., Song, Y. M., Jang, W. H., Kim, Y.
B., Yeo, J. S., Kim, J. W. and Kang, K. H. 2001. Physicochemical characteristics of longissimus muscle between the Korean native pig and Landrace. Korean J Food Sci Ani Resour 21, 142-148.

16. Jin, S. K., Kim, I. S., Hur, S. J. and Jeong, K. J. 2006. The influence of pig breeds on qualities of loin. J Anim Sci Technol 48, 747-758.

17. Jo, C., Jang, A., Jung, S., Choe, J. H., Kim, B. and Lee, K. H. 2009. Effect of dietary herb extract mix on antioxidative activity of chicken thigh Meat. J Korean Soc Food Sci Nutr 38, 302-308.

18. Kang, H. J., Park, J. D., Lee, H. Y. and Kum, J. S. 2013. Effect of microwave treatment on the physicochemical and microbiological characteristics changes of pork loin meat during storage at $4^{\circ} \mathrm{C}$. Korean J Food Preserv 20, 215-221.

19. Kang, S. M. and Lee, S. K. 2007. Comparison of the quality characteristics and aroma of $M$. Longissimus from Korean native black pigs and modem genotype pigs during vacuum packaged-chilling. Korean J Food Preserv 14, 247-255.

20. Kim, G. W., Yoo, J. Y., Kim, K. J., Lee, J. W., Kim, Y. B., Min, K. H. and Kim, S. E. 2010. Analysis of carcass characteristics by gender and carcass grade of Jeju native pig. $J$ Anim Sci Technol 52, 313-318.

21. Kim, I. S., Jin, S. K., Jo, C., Lee, M. and Jang, A. 2008. Physicochemical characteristics and fatty acid composition of the meat from Korean native black pig with different slaughter weight. J Food Sci 13, 23-27.

22. Kim, S., Lee, M., Lee, K. T., Park, S. and Song, K. B. 2004. Changes in quality of pork and beef during storage and electronic nose analysis. Korean J Food Preserv 11, 441-447.

23. Ko, M. S. and Yang, J. B. 2001. Effects of wrap and vacuum packaging on shelf life of chilled pork. Korean J Food Nutr 14, 255-262.

24. Laakonen, E., Wellington, G. H. and Skerbon, J. W. 1970. Low temperature long-time heating of bovine muscle 1. Changes in tenderness, water binding capacity, $\mathrm{pH}$ and amount of water soluble component. J Food Sci 35, 135-141.

25. Maikhunthod, B. and Intarapichet, K. O. 2005. Heat and ultrafiltration extraction of broiler meat carnosine and its antioxidant activity. Meat Sci 71, 364-374.

26. Ministry of Agriculture, Food and Rural Affairs (MAFRA). 2013. Statistics of agriculture and food of animal origin. pp. 332-333. Halla publisher, Sejong, Korea.

27. Mora, L., Sentandreu, M. A. and Toldra, F. 2008. Contents of creatine, creatinine and carnosine in porcine muscles of different metabolic types. Meat Sci 79, 709-715.

28. Park, Y. J. Volpe, S. L. and Decker, E. A. 2005. Quantification of carnosine in human plasma after dietary consumption on beef. J Agric Food Chem 53, 4736-4739.

29. U.S. Department of Agriculture (USDA). 2009. USDA nutrient data set for fresh pork (from SR), Release 2.0.

30. Witte, V. C., Krause, G. F. and Baile, M. E. 1970. A new extraction method for determining 2-thiobarbituric acid values of pork and beef during storage. J Food Sci 35, 582-585. 


\section{초록 : 재래 흑돼지 등심과 뒷다리살의 냉장저장기간 동안 품질과 di-peptides 함량 변화}

김동욱 $\cdot$ 길주애 ${ }^{1} \cdot$ 김희진 ${ }^{1} \cdot$ 김현욱 $^{2} \cdot$ 박범영 $^{2} \cdot$ 이성기 ${ }^{1} \cdot$ 장애라 ${ }^{1}$ *

('강원대학교 동물식품응용과학과, ${ }^{2}$ 국립축산과학원)

본 연구는 10 일간 냉장 저장 중 재래흑돼지 등심과 후지육의 품질변화와 항산화 di-peptide인 carnosine과 anserine 함량의 변화를 구명하기 위해 실시하였다. 등심과 후지육의 $\mathrm{pH}$ 는 저장 1 일에서 7 일까지는 $\mathrm{pH}$ 값이 5.43 5.61범위를 보였으나 저장 10 일에는 6.15 6.17으로 증가함을 나타내었다. $\mathrm{L}^{*}$ 값은 등심의 경우 저장기간 동안 유의적인 변화를 보이지 않았으나 후지육은 저장 10 일에 감소하였다. 모든 저장기간 동안 등심이 후지육보다 높 은 $\mathrm{L}^{*}$ 값을 나타내었다. 적색도를 나타내는 $\mathrm{a}^{*}$ 값은 저장 7 일까지는 유의적인 변화가 없었으나 저장 10 일에 유의적 인 감소하였으며 후지육은 저장 7일부터 감소하였다. 등심의 경우 냉장 저장 7 일부터 보수력이 유의적으로 감소 함을 보였으며 후지육의 경우 저장기간에 따른 보수력의 변화가 일정한 경향을 보이지 않았다. 흑돼지 육의 저장 초기 총균수는 등심과 후지육이 각각 4.87 과 $5.16 \log \mathrm{CFU} / \mathrm{g}$ 을 보였으며 저장 기간이 증가함에 따라 유의적으로 증가함을 나타내어 저장 10 일의 경우는 모두 $8.0 \log \mathrm{CFU} / \mathrm{g}$ 을 넘어 부패의 수준으로 진행된 것으로 판단되었다. 등심과 후지육에 함유된 carnosine 함량은 각각 $1.12 ~ 1.35 \mathrm{mg} / \mathrm{ml}, 1.17 \sim 1.30 \mathrm{mg} / \mathrm{ml}$ 이었고 모두 저장 5 일 이후 carnosine 함량이 유의적으로 감소함을 나타내었으며 재래흑돼지 등심과 후지육의 carnosine 함량은 저장 3 일까 지 유지되었고, anserine 함량의 경우는 등심은 저장 3 일, 후지육의 경우는 저장 5 일까지 초기 농도가 유지됨을 나타내었다. Carnosine과 anserine의 비율은 저장 기간이 증가하면서 등심과 후지육 모두 증가하였으며 carnosine 의 경우 특히 저장 5 일째, anserine은 저장 7 일 이후 급격한 증가를 나타내었다. DPPH 라디칼 소거능은 후지육에 서 저장 1 일차에는 $58.44 \%$ 를 보였으나 저장 10 일차에는 $24.08 \%$ 로 크게 감소함을 보였다( $p<0.05)$. 저장기간이 증가 함에 따라 TBARS와 VBN값은 유의적으로 증가하였으며 VBN은 저장 7일 이후 모두 $20 \mathrm{mg} \%$ 를 초과하였다. 본 연구결과 항산화성 di-peptide인 carnosine과 anserine은 재래흑돼지 저장기간 동안 감소하였으며 특히 anserine 은 carnosine보다 신속하게 감소하는 것으로 판단된다. 